\title{
Characterization of the Type Strain of Campylobacter coli, CIP 70.80, by Plasmid Typing
}

\author{
VÉRONIQUE STONNET, ${ }^{1 *}$ CHRISTINE HARMANT, ${ }^{2}$ CHANTAL BIZET, ${ }^{2}$ \\ AND JEAN-LUC GUESDON ${ }^{1}$ \\ Laboratoire de Prédéveloppement des Sondes ${ }^{1}$ and Collection de l'Institut Pasteur, ${ }^{2}$ \\ Institut Pasteur, 75724 Paris Cedex 15, France
}

\begin{abstract}
A 1.9-kb plasmid DNA fragment from the type strain of Campylobacter coli, CIP 70.80, was used as a probe to characterize this type strain, other $C$. coli type strains obtained from several culture collections, and other C. coli strains. A specific hybridization pattern was obtained, and this pattern can be used to identify, characterize, and follow up $C$. coli type strains in culture collections.
\end{abstract}

Proper characterization of microorganisms is very important for taxonomists when they are setting up and surveying culture collections. Type strains are given particular attention for they reflect the general characteristics of species. Workers frequently propose that a type strain should be replaced with a neotype strain (9) and also frequently reinterpret taxonomic positions (14). Recently, a proposal for a new family, the family Campylobacteraceae, was published by Vandamme and De Ley (12), and the taxonomy of the genera Campylobacter, Arcobacter, and Helicobacter has also been reviewed recently (13). In addition, minimal standards, including standards involving molecular data, have been proposed for the characterization of new species belonging to the family Campylobacteraceae (11).

Campylobacters are gram-negative bacteria which can be important human and animal pathogens $(8,10)$. Campylobacter jejuni, Campylobacter coli, and Campylobacter fetus are the most representative species and are frequently responsible for human enteritis, septicemia, and abortion, and for animal enteritis, abortion, and sterility $(4,6,15)$. C. coli CIP $70.80^{\mathrm{T}}$ was isolated from pig feces in 1970 and later was designated the type strain of the species and distributed to other culture collections. The aim of this study was to characterize and identify type strain $C$. coli CIP 70.80 and its derivatives by using molecular techniques. We describe a way to characterize this strain molecularly by using plasmid typing. A control investigation at the genome level was performed by using field inversion gel electrophoresis (FIGE).

The strains used in this study (Table 1) were grown for $48 \mathrm{~h}$ on plates containing Columbia agar supplemented with $5 \%$ sheep blood. The plates (diameter, $9 \mathrm{~cm}$ ) were incubated at $37^{\circ} \mathrm{C}$ in a jar with a microaerobic atmosphere (BBL CampyPak; Becton Dickinson, Cockeysville, Md.). The bacteria were harvested with TE $100(100 \mathrm{mM}$ Tris-HCl [pH 8], $100 \mathrm{mM}$ EDTA) and washed twice in the same buffer (5). Plasmid

TABLE 1. C. coli strains used in this study and their characteristics

\begin{tabular}{|c|c|c|c|c|c|}
\hline Strain & Plasmid content ${ }^{a}$ & Hybridization $^{b}$ & Direct source in this studyc & Derivation $^{c}$ & First isolation $^{c}$ \\
\hline C. coli $\mathrm{CIP} 70.80^{\mathrm{T}}$ & + & + & CIP & & A. Florent strain 1407 \\
\hline C. coli ATCC $33559^{\mathrm{T}}$ & + & + & ATCC & CIP $70.80^{\mathrm{T}}$ & \\
\hline C. coli CCUG $11283^{\mathrm{T}}$ & + & + & CCUG & CIP $70.80^{\mathrm{T}}$ & \\
\hline C. coli DSM $4689^{\mathrm{T}}$ & + & + & DSM & CIP $70.80^{\mathrm{T}}$ & \\
\hline C. coli $\mathrm{JCM} 2529^{\mathrm{T}}$ & + & + & $\mathrm{JCM}$ & CIP $70.80^{\mathrm{T}}$ & \\
\hline C. coli $\mathrm{LMG} 8847^{\mathrm{T}}$ & + & + & LMG & CIP $70.80^{\mathrm{T}}$ & \\
\hline "C. coli LMG $6440^{\mathrm{T}} "$ & + & + & UB & $\mathrm{LMG} \leftarrow \mathrm{CIP} 70.80^{\mathrm{T}}$ & \\
\hline "C. coli CIP $70.80^{\mathrm{T}} "$ & + & + & UB & CIP $70.80^{\mathrm{T}}$ & \\
\hline C. coli NCTC $11366^{\mathrm{T}}$ & + & + & NCTC & CIP $70.80^{\mathrm{T}}$ & \\
\hline C. coli CIP 70.54 & - & - & CIP & & A. Florent strain 3949 \\
\hline C. coli CIP 70.77 & - & - & CIP & & A. Florent strain P2 \\
\hline C. coli CIP 70.78 & - & - & CIP & & A. Florent strain P3 \\
\hline C. coli CIP 70.79 & - & - & CIP & & A. Florent strain P6 \\
\hline C. coli CIP 70.81 & + & + & CIP & & A. Florent strain P9 \\
\hline C. coli CIP 71.5 & + & - & CIP & & A. Florent strain P875 \\
\hline C. coli CIP $103753^{d}$ & + & - & CIP & BM & HB \\
\hline C. coli A $630^{d}$ & - & - & HUSP & & HUSP \\
\hline
\end{tabular}

$a+$, plasmid DNA present; -, plasmid DNA absent.

${ }^{b}+$, hybridization with the 1.9-kb DNA fragment; - , no hybridization with the 1.9-kb DNA fragment.

c ATCC, American Type Culture Collection, Rockville, Md.; BM, bioMérieux, Marcy l'Etoile, France; CCUG, Culture Collection of the University of Gøteborg, Gøteborg, Sweden; CIP, Collection de l'Institut Pasteur, Paris, France; DSM, Deutsche Sammlung von Mikroorganismen, Braunschweig, Germany; HB, Hôpital Pellegrin, Bordeaux, France; HUSP, Hôpital Universitaire Saint-Pierre, Brussels, Belgium; JCM, Japan Collection of Microorganisms, Wako, Saitama, Japan; LMG, Laboratorium voor Microbiologie, Universiteit Gent, Ghent, Belgium; NCTC, National Collection of Type Cultures, London, United Kingdom; UB, University of Berne, Berne, Switzerland.

${ }^{d}$ Human clinical isolate.

\footnotetext{
* Corresponding author. Mailing address: Laboratoire de Prédévelop pement des Sondes, Institut Pasteur, 25, rue du Dr. Roux, 75724 Paris Cedex 15, France.
} 
DNAs were extracted by the rapid alkaline lysis method (1), and whole-cell DNAs were isolated by using the lysozymesodium dodecyl sulfate (SDS)-proteinase $\mathrm{K}$ method described by Fennell et al. (3). Whole-cell and plasmid DNAs were digested with restriction enzymes HindIII and DraI by using the instructions of the manufacturer (Boehringer, Mannheim, Germany). The restriction fragments were separated by electrophoresing them on a $1.2 \%$ agarose gel with TAE buffer (0.04 M Tris-acetate, $0.001 \mathrm{M}$ EDTA), denatured, neutralized, and transferred to Hybond-N filters (Amersham, Arlington Heights, Ill.) by Southern blotting. The probe used for hybridization was the 1.9-kb HindIII DNA fragment obtained after restriction of $C$. coli CIP $70.80^{\mathrm{T}}$ ( $\mathrm{T}=$ type strain) plasmid DNA, electroelution from the electrophoresis gel, and cloning into vector pUC18 (7). For hybridization reactions, the probe was freed from the vector and labeled with $\left[\alpha-{ }^{32} \mathrm{P}\right] \mathrm{dCTP}$ (Amersham International, Amersham, United Kingdom) by using a random priming kit (Boehringer). The filters were prehybridized for $1 \mathrm{~h}$ at $65^{\circ} \mathrm{C}$ in a buffer containing $6 \times \mathrm{SSC}, 5 \times$ Denhardt's solution, $0.5 \%$ SDS, and $100 \mu \mathrm{g}$ of denatured salmon sperm DNA per $\mathrm{ml}(1 \times \mathrm{SSC}$ is $150 \mathrm{mM} \mathrm{NaCl}$ plus $15 \mathrm{mM}$ sodium citrate [pH 7.0]; $1 \times$ Denhardt's solution is $0.02 \% \mathrm{Fi}-$ coll, $0.02 \%$ polyvinylpyrrolidone, and $0.02 \%$ bovine serum albumin). Hybridization was carried out at $65^{\circ} \mathrm{C}$ for $18 \mathrm{~h}$ in fresh prehybridization buffer supplemented with the radiolabeled probe $\left(10^{6} \mathrm{cpm} / \mu \mathrm{g}\right.$ of probe). After hybridization and stringent washing (twice with $2 \times \mathrm{SSC}$ at $65^{\circ} \mathrm{C}$ for $10 \mathrm{~min}$, once with $2 \times$ SSC $-0.1 \%$ SDS at $65^{\circ} \mathrm{C}$ for $30 \mathrm{~min}$, and once with $0.1 \times$ SSC at $65^{\circ} \mathrm{C}$ for $10 \mathrm{~min}$ ), the filters were briefly air dried and exposed to Kodak XAR5 film with intensifying screens at $-70^{\circ} \mathrm{C}$.

For FIGE analyses, DNAs were extracted from Campylobacter strains and restricted with SmaI or SalI as described by Chang and Taylor (2). FIGE was performed with a $1 \%$ agarose gel in TBE buffer ( $0.045 \mathrm{M}$ Tris-borate, $0.001 \mathrm{M}$ EDTA) at 250 $\mathrm{V}$ and $4^{\circ} \mathrm{C}$ for $22 \mathrm{~h}$ by using a field inversion pulse controller (model PC750; Hoefer Scientific Instruments, San Francisco, Calif.). The initial pulse durations were $1.5 \mathrm{~s}$ in the forward direction and $0.5 \mathrm{~s}$ in the reverse direction with a ramp factor value of 0.5 (i.e., the final pulse durations were 18 and $6 \mathrm{~s}$, respectively).

An analysis of the plasmid content of C. coli CIP $70.80^{\mathrm{T}}$ revealed that this strain contains a $70-\mathrm{kb}$ low-copy-number plasmid and two 3.3-kb high-copy-number cryptic plasmids (8a). Digestion of the whole-plasmid DNA with enzyme HindIII yielded two major DNA fragments, a 1.6-kb fragment and a 1.9-kb fragment, which originated from the two small cryptic plasmids (Fig. 1A). These two DNA fragments exhibit extensive homology, as revealed by a DNA sequence analysis (8a). In this study, we used the $1.9-\mathrm{kb}$ fragment as a probe to characterize and/or differentiate $C$. coli CIP $70.80^{\mathrm{T}}$, its derivatives (i.e., C. coli type strains from other culture collections), and other $C$. coli strains. Type strain CIP 70.80 and all of its derivatives yielded the same restriction and hybridization pattern in which two main fragments (1.6 and $1.9 \mathrm{~kb}$ ) strongly hybridized to the probe (Fig. 1). After longer exposure times $(1 \mathrm{~h})$ three additional, fainter bands appeared (data not shown). The pattern obtained for $C$. coli CIP 70.81 DNA had a band at 1.6 $\mathrm{kb}$ and a second band at $3 \mathrm{~kb}$. Two of the three additional fainter bands also appeared in this strain after longer exposure times. None of the other C. coli DNAs hybridized to the probe. When DraI was used to digest the DNAs, the same strain grouping was obtained (data not shown).

The identical patterns found for type strain $C$. coli CIP 70.80 and its derivatives obtained from other culture collections suggest that these strains have not diverged from the original type strain, although successive subcultures have been made. In

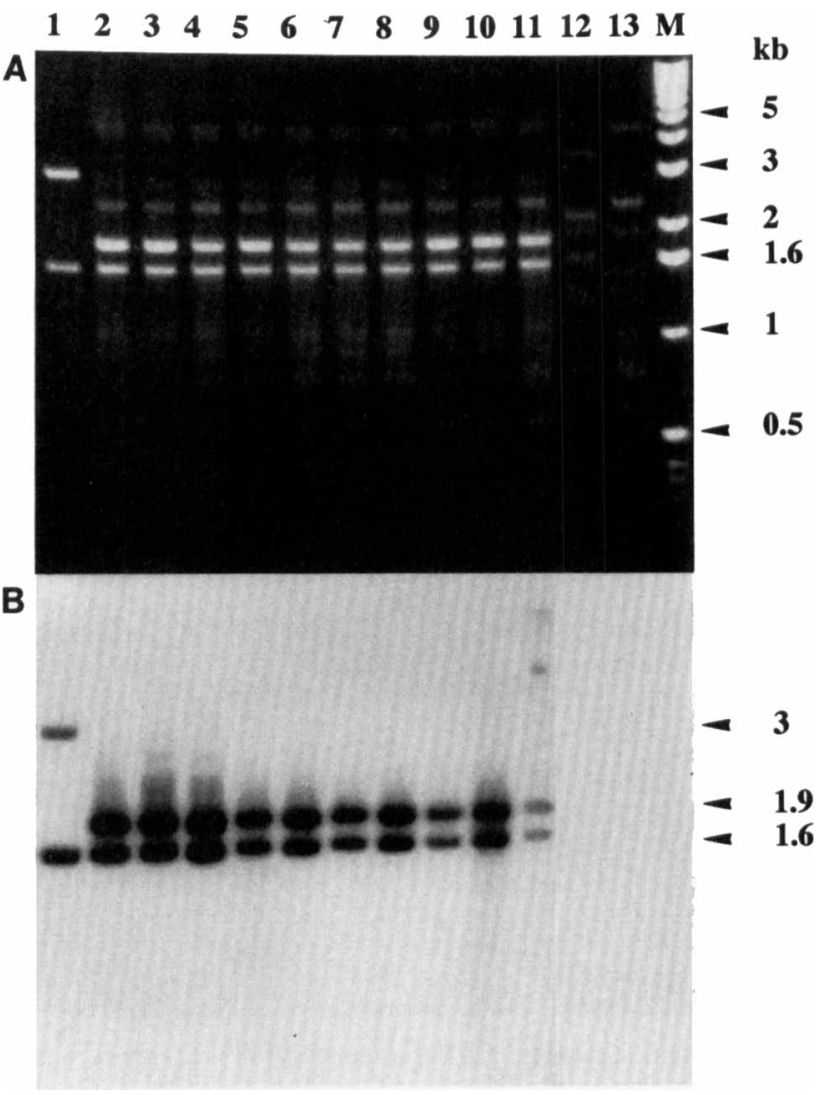

FIG. 1. Characterization of C. coli strains by plasmid typing: HindIII restriction fragment length polymorphism of plasmid DNAs obtained after gel electrophoresis and ethidium bromide staining (A) and Southern blot of whole-cell DNAs digested with HindIII, probed with the ${ }^{32} \mathrm{P}$-labeled $1.9-\mathrm{kb}$ plasmid DNA fragment from C. coli CIP $70.80^{\mathrm{T}}$, and autoradiographed for $15 \mathrm{~min}$ (B). Lane 1, C. coli CIP 70.81 ; lane $2, C$. coli CIP $70.80^{\mathrm{T}}$; lane $3, C$. coli ATCC $33559^{\mathrm{T}}$; lane 4, C. coli CCUG $11283^{\mathrm{T}}$; lane 5 , C. coli DSM 4689 ; lane $6, C$. coli $\mathrm{JCM} 2529^{\mathrm{T}}$; lane 7, $C$. coli $\mathrm{LMG} 8847^{\mathrm{T}}$; lane 8 , " $C$. coli $\mathrm{LMG} 6440^{\mathrm{T}}$ "; lane 9, "C. coli CIP $70.80^{\mathrm{T}}$ "; lane $10, C$. coli NCTC $11366^{\mathrm{T}}$; lane 11, C. coli CIP $70.80^{\mathrm{T}}$ after subculturing for 400 generations; lane 12, C. coli CIP 103753; lane 13, C. coli CIP 71.5; lane M, 1-kb molecular ladder (Gibco BRL, Gaithersburg, Md.).

vitro subculturing of type strain CIP 70.80 for about 400 generations (assuming a generation time of $1 \mathrm{~h}$ ) under nonselective conditions did not result in a loss of plasmids. On the other hand, although C. coli CIP $70.80^{\mathrm{T}}$ and CIP 70.81 seem to be very closely related, as suggested by the high levels of hybridization pattern homology obtained with their plasmids, there is no doubt that they are distinct organisms (Fig. 1). Moreover, whole-cell or plasmid DNAs from the other $C$. coli strains tested, especially $C$. coli CIP 103753 , which is used as a quality control strain for API products, did not hybridize to the $1.9-\mathrm{kb}$ probe (Fig. 1B and Table 1). Whole-cell DNAs from 11 other Campylobacter strains (C. jejuni CIP $70.2^{\mathrm{T}}$, Campylobacter lari CIP $102722^{\mathrm{T}}$, a Campylobacter upsaliensis clinical isolate, Campylobacter fetus subsp. fetus CIP 53.95, C. fetus subsp. venerealis CIP $68.29^{\mathrm{T}}$, a Campylobacter hyointestinalis clinical isolate, Campylobacter sputorum biovar sputorum CIP $103749^{\mathrm{T}}$, C. sputorum biovar bubulus CIP $53.103^{\mathrm{T}}$, C. sputorum biovar fecalis CIP 12014, a Campylobacter concisus clinical isolate, and a Campylobacter curvus clinical isolate) and from four non-Campylobacter strains (Arcobacter cryaerophilus CIP 104014, Helicobacter pylori CIP 101260, Escherichia coli HB101, and Salmonella enterica subsp. enterica serotype Typhimurium strain C53) also failed to hybridize to the probe. 


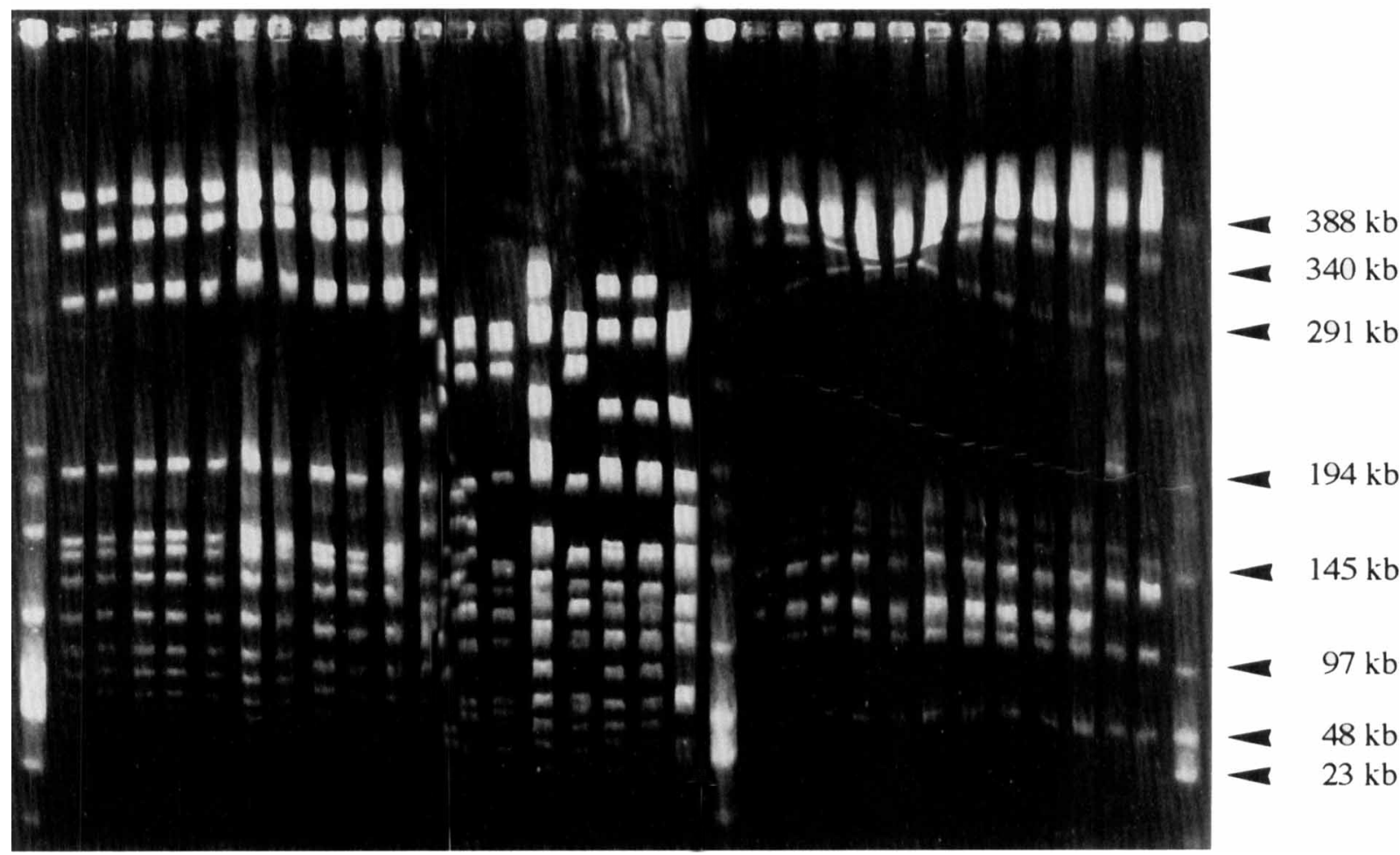

FIG. 2. FIGE analysis of $C$. coli DNAs restricted with SmaI (lanes 2 to 19) or Sall (lanes 21 to 32). Lanes 1, 20, and 33, $\lambda$ ladder PFG marker (New England Biolabs); lanes 2 and 21, C. coli CIP $70.80^{\mathrm{T}}$; lanes 3 and $22, C$. coli ATCC $33559^{\mathrm{T}}$; lanes 4 and 23, C. coli CCUG $11283^{\mathrm{T}}$; lanes 5 and $24, C$. coli DSM $4689^{\mathrm{T}}$; lanes 6 and 25 ,

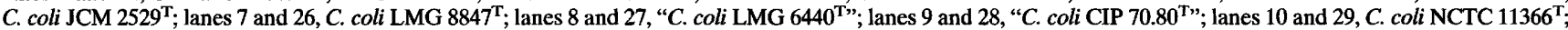
lanes 11 and $30, C$. coli CIP $70.80^{\mathrm{T}}$ after subculturing for 400 generations; lanes 12 and $31, C$. coli CIP $70.81 ;$ lanes 13 and $32, C$. coli CIP 103753 ; lane $14, C$. coli CIP 71.5; lane 15, C. coli CIP 70.79; lane 16, C. coli CIP 70.78; lane 17, C. coli CIP 70.77; lane 18, C. coli CIP 70.54; lane 19, C. coli A630.

FIGE analysis of the $C$. coli strains confirmed the genomic identity between type strain $C$. coli CIP 70.80 and its derivatives, whereas different patterns were obtained with $C$. coli CIP 70.81 as well as the other C. coli strains tested (Fig. 2).

Our results indicate that molecular typing in which the 1.9-kb plasmid DNA probe from C. coli CIP $70.80^{\mathrm{T}}$ is used is a reliable method for characterizing the $C$. coli type strain and for studying its possible evolution.

We are grateful to Bénédicte Catimel for excellent technical assistance with the FIGE experiments. We also thank Y. Benno, A. Burnens, J. P. Butzler, E. Falsen, D. Janssens, E. Lang, R. Owen, and $P$. Pienta for providing the $C$. coli type strains equivalent to $C$. coli $\mathrm{CIP}$ $70.80^{\mathrm{T}}$.

\section{REFERENCES}

1. Birnboim, H. C., and J. Doly. 1979. A rapid alkaline extraction procedure for screening recombinant plasmid DNA. Nucleic Acids Res. 7:1513-1523.

2. Chang, N., and D. E. Taylor. 1990. Use of pulsed-field agarose gel electrophoresis to size genomes of Campylobacter species and to construct a SalI map of Campylobacter jejuni UA580. J. Bacteriol. 172:5211-5217.

3. Fennell, C. L., P. A. Totten, T. C. Quinn, D. L. Patton, K. K. Holmes, and W. E. Stamm. 1984. Characterization of Campylobacter-like organisms isolated from homosexual men. J. Infect. Dis. 149:58-66.

4. Grifiths, P. L., and R. W. A. Park. 1990. Campylobacters associated with human diarrhoeal disease. J. Appl. Bacteriol. 69:281-301.

5. Majewski, S. I. H., and C. S. Goodwin. 1988. Restriction endonuclease analysis of the genome of Campylobacter pylori with a rapid extraction meth- od: evidence for considerable genomic variation. J. Infect. Dis. 157:465-471. 6. Penner, J. L. 1988. The genus Campylabacter: a decade of progress. Clin Microbiol. Rev, 1:157-172.

7. Sambrook, J., E. F. Fritsch, and T. Maniatis. 1989. Molecular cloning: a laboratory manual, 2nd ed. Cold Spring Harbor Laboratory, Cold Spring Harbor, N.Y.

8. Smibert, R. M. 1984. Genus Campylobacter Sebald and Véron 1963, 907 p. 111-118. In N. R. Krieg and J. G. Holt (ed.), Bergey's manual of systematic bacteriology, vol. 1. Williams \& Wilkins Co., Baltimore

8a.Stonnet, V., and J.-L. Guesdon. Submitted for publication.

9. Tanasupawat, S., S. Okada, M. Kozaki, and K. Komagata. 1993. Characterization of Pediococcus pentosaceus and Pediococcus acidilactici strains and replacement of the type strain of $P$. acidilactici with the proposed neotype DSM 20284. Int. J. Syst. Bacteriol. 43:860-863.

10. Tenover, F. C., and C. L. Fennell. 1992. The genera Campylobacter and Helicobacter, p. 3488-3511. In A. Balows, H. G. Trüper, M. Dworkin, W. Harder, and K.-H. Schleifer (ed.), The prokaryotes, vol. 4. Springer Verlag, New York.

11. Ursing, J. B., H. Lior, and R. J. Owen. 1994. Proposal of minimal standards for describing new species of the family Campylobacteraceae. Int. J. Syst. Bacteriol. 44:842-845.

12. Vandamme, P., and J. De Ley. 1991. Proposal for a new family: Campylobacteraceae. Int. J. Syst. Bacteriol. 41:451-455.

13. Vandamme, P., and H. Goossens. 1992. Taxonomy of Campylobacter, Arcobacter and Helicobacter: a review. Zentralbl. Bakteriol. 276:447-472.

14. Van Zyl, E., and P. L. Steyn. 1992. Reinterpretation of the taxonomic position of Xanthomonas maltophilia and taxonomic criteria in this genus. Request for an opinion. Int. J. Syst. Bacteriol. 42:193-198.

15. Walker, R. I., M. B. Caldwell, E. C. Lee, P. Guerry, T. J. Trust, and G. M. Ruiz-Palacios. 1986. Pathophysiology of Campylobacter enteritis. Microbiol. Rev. 50:81-94. 